Jurnal SPORTIF: Jurnal Penelitian Pembelajaran

Vol. 6 No. 1, April 2020, pp. 199-215

doi) https://doi.org/10.29407/js_unpgri.v6i1.14252

\title{
Permainan tradisional: suatu pendekatan dalam mengembangkan physical literacy siswa sekolah dasar
}

\section{Traditional games: an approach to developing students physical literacy in elementary school}

\section{Uray Gustian}

Department of Sports Coaching Education, Universitas Tanjungpura, Jl. Prof. Dr. H. Hadari Nawawi, Bansir Laut, Southeast Pontianak District, Pontianak, West Kalimantan Province, 78124, Indonesia

Received: 26 February 2020; Revised: 6 April 2020; Accepted: 17 April 2020

\begin{abstract}
Abstrak
Physical Literacy (PL) merupakan keterampilan yang harus dimiliki siswa sebagai akibat adanya pergeseran capaian pembelajaran pendidikan jasmani (penjas). Akan tetapi, belum banyak bentuk aktivitas pembelajaran yang bisa digunakan untuk mengembangkan PL. Untuk itu, penelitian ini dilakukan bertujuan untuk menemukan aktivitas pembelajaran yang dapat mengembangkan PL. Eksperimen dilakukan dengan mengimplementasikan permainan tradisional yang dimodifikasi terdiri atas tujuh permainan yaitu lempar kaleng, lempar telur penyu, sumpitan, balap balon, estafet kelereng, bakiak, dan engklek. Penelitian diujicobakan terhadap siswa sekolah dasar kelas satu yang berjumlah lima puluh siswa. Hasil penelitian menunjukkan adanya peningkatan pemahaman siswa dalam melakukan permainan, keterampilan gerak, kesenangan, dan secara kumulatif telah terjadi peningkatan pencapaian PL siswa. Peningkatan terjadi disebabkan permainan tradisional yang dimodifikasi sesuai dengan karakteristik siswa, disusun dengan mempertimbangkan prinsip dan aspek pengembangan aktivitas pembelajaran. Berdasarkan hasil tersebut, disimpulkan bahwa penggunaan permainan tradisional yang dimodifikasi dapat dapat meningkatkan PL siswa sekolah dasar.
\end{abstract}

Kata kunci: permainan tradisional, physical literacy, siswa sekolah dasar.

\begin{abstract}
Physical literacy (PL) is a skill that must be possessed by students as a result of a shift in physical education learning achievements. However, there are not many forms of learning activities that can be used to develop. For this reason, the study was conducted aiming to find learning activities that could develop PL. Experiments carried out by implementing a modified traditional game consisting of seven games, namely lempar kaleng, lempar telur penyu, sumpitan, balap balon, estafet kelereng, bakiak, dan engklek. The study was tested on first grade elementary school students, totaling fifty students. The results showed an increase in students' understanding in playing games, movement skills, happiness, and cumulatively there was an increase in student achievement in PL. The increase occurred due to traditional games that were modified in accordance with the characteristics of students, arranged by considering the principles and aspects of developing learning activities. Based on these results, it was concluded that the use of modified traditional games could improve elementary school students' PL.
\end{abstract}

Keywords: elementary school students, physical literacy, traditional games.

Correspondence author: Uray Gustian, Universitas Tanjungpura, Indonesia.

Email: uray.gustian@fkip.untan.ac.id 


\section{PENDAHULUAN}

Era abad ke-21 telah terjadi perkembangan yang sangat pesat khususnya perkembangan teknologi informasi dan otomatisasi. Berkenaan dengan hal tersebut, pendidikan harus mampu mempersiapkan siswa untuk mampu berpikir kritis, kreatif, kolaboratif, komunikatif, dan literasi (Wijaya, Sudjimat, \& Nyoto, 2016). Seiring hal tersebut, capaian pembelajaran pendidikan jasmani (penjas) pada saat ini secara umum sudah mengarah kepada mendorong siswa memiliki motivasi dan kemampuan untuk memahami, berkomunikasi, menerapkan pengetahuan, menganalisis gerakan secara kritis dengan berbagai cara, dan menunjukkan fleksibilitas gerak dengan percaya diri, kompeten, dan kreatif atau yang lebih dikenal dengan physical literacy (PL) (Higgs, Balyi, Way, Cardinal, Norris, \& Bluechardt, 2008; Butler \& Griffin, 2010).

PL diartikan sebagai pondasi dalam pembentukan perilaku, kesadaran, pemahaman tentang pola hidup aktif, kesenangan dalam melakukan aktivitas, kemampuan untuk mengidentifikasi, memahami, menginterpretasikan, merespon secara efektif dalam pemanfaatan kemampuan gerak tubuh dalam konteks yang luas dan bervariasi (Tremblay \& Llyod, 2010; Whitehead, 2013). Dalam konteks penelitian ini, PL merupakan pengembangan keterampilan gerak dasar dan kepercayaan diri sehingga siswa memiliki motivasi dan kemampuan untuk memahami, kepercayaan terhadap kemampuan dirinya, menerapkan pola hidup sehat dengan gaya hidup aktif, dan memiliki keterampilan gerak dasar yang baik.

Mengingat pentingnya pengembangan PL bagi siswa, seharusnya sudah menjadi perhatian penuh dari para guru yang mengajar penjas khususnya di Sekolah Dasar (SD) yang ada di Indonesia. Hal ini disebabkan penjas di SD memiliki peranan penting dalam perkembangan siswa yaitu mendorong siswa untuk belajar gerak sehingga dapat meningkatkan keterampilan gerak, mengembangkan kebugaran meningkatkan pengetahuan tentang gerak, menstimulasi agar aktif dalam melakukan gerak (Domville, Watson, Richardson, \& Graves, 2019). 
Pentingnya penjas di SD juga disebabkan banyak siswa SD yang rnengalami panyakit degeneratif yang diakibatkan kurangnya dalam melakukan aktivitas gerak (inactivity) yaitu noncomunicate diseases (NCDs) dan gangguan kesehatan umum lainnya seperti obesitas, serangan jantung, hypertensi, kanker, dan diabetes (WHO, 2014). Selain itu, siswa juga mengalami keterlambatan dalam perkembangan sosial, emosional, dan kognitif yang terjadi sepanjang hidupnya, memiliki keterampilan gerak rendah, menunjukkan sikap kurang aktif dalam belajar dibanding siswa yang memiliki keterampilan gerak baik (Williams, Pfeiffer, O'neill, Dowda, Mclver, Brown, \& Pate, 2008), penurunan dalam kemampuan kosa kata dan keterampilan matematika yang dikarenakan siswa sulit untuk memusatkan perhatian, dan keterlambatan dalam keterampilan gerak (Pagani, Fitzpatrick, \& Barnett, 2013).

Terkait dengan permasalahan tersebut diperlukan suatu upaya guna melaksanakan pembelajaran yang tepat dan sesuai dengan capaian pembelajaran pendidikan jasmani untuk SD saat ini. Adapun dalam melaksanakan penjas harus dilaksanakan secara konsisten dilaksanakan dengan cara yang menyenangkan bagi siswa (Domville, Watson, Richardson, \& Graves, 2019). Akan tetapi, yang menjadi permasalahan PL merupakan suatu konsep capaian pembelajaran yang baru dan masih belum banyak bentuk aktivitas pembelajaran yang bisa digunakan untuk mengembangkan PL siswa (Corbin, 2016).

Berdasarkan hal tersebut, diperlukan suatu upaya guna menemukan pendekatan pembelajaran yang dapat digunakan untuk meningkatkan PL siswa SD. Salah satu upaya yang dilakukan yaitu melakukan penelitian dengan menggunakan pendekatan permainan tradisional. Hal ini disebabkan permainan tradisional memiliki dampak positif terhadap perkembangan psikis, fisik, dan membentuk karakter siswa karena diajarkan untuk jujur dan melatih gerak psikomotor, meningkatkan kemampuan berbahasa dan sosial emosional, melatih anak untuk memanajemen konflik, dan memecahkan masalah yang 
dihadapinya (Kurniati, 2016). Hal ini menjadikan permainan tradisional dapat dijadikan alternatif yang tepat dalam pengernbangan PL.

Penelitian dilakukan dengan penggunaan permainan tradisional yang tata cara dan peralatan permainan disesuaikan dengan karakteristik siswa dan kondisi lingkungan. Sasaran penelitian adalah siswa SD kelas bawah khususnya kelas satu. Hal ini mengingat kelas satu merupakan awal rnemasuki sekolah dasar dan baru melewati pendidikan di Taman Kanak-kanak sehingga pendekatan pembelajaran dengan menggunakan permainan tradisional dapat digunakan.

\section{METODE}

Eksperimen yang dilakukan menggunakan desain one shot case study. Penelitian dilakukan dengan mengimplementasikan permainan tradisional yang sebelumnya dimodifikasi alat dan aturan bermainnya pada pembelajaran penjas SD. Permainan tradisional yang digunakan terdiri atas tujuh permainan yang dibagi dalam dua kali ujicoba dan dua pertemuan untuk masing-masing ujicoba. Adapun permainan tradisional yang digunakan yaitu permainan lempar kaleng, lempar telur penyu, dan sumpitan untuk pertemuan pertama dan permainan balap balon, estafet kelereng, bakiak, dan engklek untuk pertemuan kedua.

Pelaksanaan ujicoba penelitian dilakukan dengan membagi siswa menjadi beberapa kelompok dengan jumlah empat sampai lima siswa untuk masing-masing. Setiap kelompok akan berlomba untuk menyelesaikan tugas-tugas yang terdapat pada permainan tradisional. Peran guru adalah sebagai fasilitator dan pengawas untuk memastikan pelaksanan permainan sesuai yang diharapkan. Sebelum melaksanakan setiap permainan, guru menjelaskan kepada siswa mengenai tata cara melakukan permainan. Selain itu juga, peran guru sebagai observer dalam mengobservasi perilaku siswa ketika melakukan permainan. Setiap aktivitas siswa melakukan permainan didokumentasikan melalui rekaman video.

Subyek penelitian adalah siswa SD kelas satu dengan jumlah partisipan lima puluh siswa. Teknik pengumpulan data menggunakan 
teknik observasi dengan menggunakan instrumen rubrik penilaian. Observasi dilakukan setiap akhir ujcoba dan pengambilan data dilakukan terhadap pemahaman siswa, keterampilan gerak, dan perilaku siswa. Aspek yang di observasi mencakup pemahaman (mengerti dan mampu melakukan), keterampilan gerak (keterampilan gerak fundamental), perilaku anak (kesenangan dalam melakukan). Rubrik penilaian menggunakan skala Likert satu sampai empat. Analisis data dilakukan menggunakan deksriptif kuantitatif dengan cara memaparkan disribusi frekuensi dan mean untuk masing-masing aspek.

\section{HASIL}

Pada penilaian uji coba pertama untuk tingkat pemahaman siswa dalam melakukan permainan tradisional lebih dominan berada pada pada kategori kurang baik dengan jumlah 18 orang siswa (32\%). Secara keseluruhan berjumlah 122 dan rata-rata pencapaian hasil penilaian siswa berada pada kategori kurang baik dengan nilai 2.44. Pada uji coba kedua tingkat pemahaman siswa meningkat lebih didominan pada kategori baik yaitu sebanyak 19 siswa (38\%). Berdasarkan hasil keseluruhan yaitu 148 dan nilai rata-rata yang dicapai siswa adalah 2,96 atau naik sebesar 0,52 menjadi kategori baik. Hasil penilaian tingkat pemahaman siswa secara lengkap dijabarkan pada tabel 1 .

Pada tingkat pemahaman, terjadi peningkatan sebesar 0,52 merupakan hal yang sangat berarti yaitu peningkatan pemahaman yang terjadi pada siswa termasuk tinggi. Selain itu juga, peningkatan terjadi karena permainan yang disusun mudah untuk dimengerti oleh siswa dan permainan tradisional yang dipilih dekat dangan dunia siswa. Hal ini berakibat pada siswa dengan mengenal dengan tatacara melakukan permainan yang disusun. 
Tabel 1. Hasil Penilaian Tingkat Pemahaman Siswa

\begin{tabular}{lccccc}
\hline \multirow{2}{*}{ Rentang Nilai } & \multicolumn{3}{c}{ Ujicoba ke-I } & \multicolumn{3}{c}{ Ujicoba ke-II } & \multirow{2}{*}{ Kategori } \\
& $\mathrm{f}$ & $\%$ & $\mathrm{f}$ & $\%$ & \\
\hline $3,26-4,00$ & 8 & 16 & 15 & 32 & Sangat baik \\
$2,51-3,25$ & 16 & 32 & 19 & 38 & Baik \\
$1,76-2,50$ & 18 & 36 & 12 & 24 & Kurang baik \\
$1,00-1,75$ & 6 & 12 & 3 & 6 & Tidak baik \\
Rata-rata & 2,44 & - & 2,96 & - & \\
Jumlah & 122 & 100 & 148 & 100 & \\
\hline
\end{tabular}

Penilaian tingkat kemampuan gerak siswa yang terdapat pada tabel 2, pada uji coba pertama tingkat kemampuan gerak siswa cenderung baik. Hasil ini diperoleh dari hasil yang dicapai siswa dominan berada pada kategori sangat baik dengan jumlah 15 siswa (30\%) dan diikuti kategori baik dengan 12 siswa (24\%). Berdasarkan perhitungan rata-rata penilaian, kemampuan gerak siswa berada pada kategori baik dengan nilai 2,58. Pada uji coba kedua, kemampuan gerak siswa masih dominan berada kategori sangat baik hanya saja terjadi peningkatan jumlah siswa yang berada pada kategori tersebut yaitu 19 siswa (38\%) atau naik sebanyak 4 orang siswa (8\%). Hasil ini juga diikuti dengan 15 (30\%) siswa yang memperoleh kategori baik atau naik 3 orang siswa (6\%). Pada kategori kurang baik tidak terjadi perubahan dan pada kategori tidak baik menurun menjadi 6 siswa (12). Nilai rata-rata yang dicapai siswa yaitu 2,94 dengan kategori baik atau naik sebesar 0,38 dari uji coba pertama.

Tabel 2. Hasil Penilaian Tingkat Kemampuan Gerak Siswa Uji Coba Kedua

\begin{tabular}{|c|c|c|c|c|c|}
\hline \multirow{2}{*}{ Rentang Nilai } & \multicolumn{2}{|c|}{ Ujicoba ke-I } & \multicolumn{2}{|c|}{ Ujicoba ke-II } & \multirow{2}{*}{ Kategori } \\
\hline & f & $\%$ & $f$ & $\%$ & \\
\hline $3,26-4,00$ & 15 & 30 & 19 & 38 & Sangat baik \\
\hline $2,51-3,25$ & 12 & 24 & 15 & 30 & Baik \\
\hline $1,76-2,50$ & 10 & 20 & 10 & 20 & Kurang baik \\
\hline $1,00-1,75$ & 13 & 26 & 6 & 12 & Tidak baik \\
\hline Rata-rata & 2,58 & - & 2,94 & - & \\
\hline Jumlah & 129 & 100 & 147 & 100 & \\
\hline
\end{tabular}

Penilaian tingkat kesenangan siswa yang terdapat pada tabel 3 diperoleh hasil pada uji coba pertarna dalam melakukan aktivitas 
permainan menunjukkan seluruh siswa senang dalam melakukan permainan. Hasil ini tunjukkan dengan 23 siswa (46\%) berada pada kategori sangat senang diikuti dengan 15 siswa (30\%) yang senang, 11 siswa $(22 \%)$ kurang baik, dan tidak ada satupun siswa yang tidak senang melakukan aktivitas permainan tradisional. Berdasarkan hasil perhitungan rata-rata penilaian yang dilakukan siswa berada pada kategori senang dengan nilai 3,18 dengan kategori senang.

Selanjutnya pada uji coba kedua jumlah terjadi peningkatan tingkat kesenangan siswa dalam melakukan permainan. Sebanyak 34 siswa (68\%) sangat senang, 16 (32\%) siswa senang, dan tidak satupun siswa yang kurang senang dan tidak senang melakukan permainan tradisional. Berdasarkan perhitungan nilai rata-rata nilai yang diperoleh siswa sebesar 3,68 dengan kategori sangat senang atau naik sebesar 0,50 dari ujicoba pertama. Hasil tersebut menunjukkan pada uji coba kedua keseluruhan siswa menyenangi permainan yang di ujicobakan.

Tabel 3. Hasil Penilaian Tingkat Kesenangan Siswa

\begin{tabular}{|c|c|c|c|c|c|}
\hline \multirow{2}{*}{ Rentang Nilai } & \multicolumn{2}{|c|}{ Ujicoba ke-I } & \multicolumn{2}{|c|}{ Ujicoba ke-II } & \multirow{2}{*}{ Kategori } \\
\hline & $f$ & $\%$ & f & $\%$ & \\
\hline $3,26-4,00$ & 23 & $46 \%$ & 34 & $68 \%$ & Sangat senang \\
\hline $2,51-3,25$ & 15 & $32 \%$ & 16 & $32 \%$ & Senang \\
\hline $1,76-2,50$ & 11 & $22 \%$ & 0 & $0 \%$ & Kurang senang \\
\hline $1,00-1,75$ & 0 & $0 \%$ & 0 & $0 \%$ & Tidak senang \\
\hline Rata-rata & 3,18 & - & 3,68 & - & \\
\hline Jumlah & 159 & 100 & 184 & 100 & \\
\hline
\end{tabular}

Perhitungan pencapaian PL siswa dapat dilihat pada tabel 4 yang penentuannya berdasarkan pada hasil analisis nilai kumulatif dari nilai pemahaman, kemampuan gerak, dan tingkat kesenangan. Adapun hasil penilaian uji coba pertama menunjukkan pencapaian PL siswa dominan berada pada kategori sangat baik sebanyak 15 siswa (30\%), baik sebanyak 15 siswa (30\%), kurang baik 14 siswa (28\%), dan tidak baik (12\%). Berdasarkan hasil nilai rata-rata, PL yang dicapai siswa berada pada kategori baik dengan nilai 2.78. 
Selanjutnya pada uji coba kedua pencapaian PL juga dominan berada pada kategori sangat baik dengan 23 siswa (46\%) dan telah terjadi peningkatan $16 \%$ dari uji coba pertama. Selain itu juga, pada kategori kurang baik telah mengalami penurunan menjadi 7 siswa (14\%) dan kategori tidak baik hanya 3 siswa $(6 \%)$. Nilai rata-rata yang diperoleh sebesar 3.2 atau naik sebesar 0.42 . Hasil ini menunjukkan adanya peningkatan pencapaian PL siswa yang merupakan akibat hasil belajar siswa dengan melakukan permainan tradisional.

Tabel 4. Hasil Pencapaian PL Siswa

\begin{tabular}{|c|c|c|c|c|c|}
\hline \multirow{2}{*}{ Rentang Nilai } & \multicolumn{2}{|c|}{ Ujicoba ke-I } & \multicolumn{2}{|c|}{ Ujicoba ke-II } & \multirow{2}{*}{ Kategori } \\
\hline & $f$ & $\%$ & $f$ & $\%$ & \\
\hline $3,26-4,00$ & 15 & 30 & 23 & 46 & Sangat baik \\
\hline $2,51-3,25$ & 15 & 30 & 17 & 34 & Baik \\
\hline $1,76-2,50$ & 14 & 28 & 7 & 14 & Kurang baik \\
\hline $1,00-1,75$ & 6 & 12 & 3 & 6 & Tidak baik \\
\hline Rata-rata & 2,78 & - & 3,2 & - & \\
\hline Jumlah & 122 & 100 & 148 & 100 & \\
\hline
\end{tabular}

Berdasarkan rekapitulasi hasil penilaian pada saat uji coba pada gambar 1 menunjukkan bahwa hasil penilaian yang diperoleh siswa pada pertemuan kedua mengalami peningkatan dibandingkan pertemuan pertama. Hal ini terlihat dari hasil penilaian pemahaman, kemampuan gerak, tingkat kesenangan.

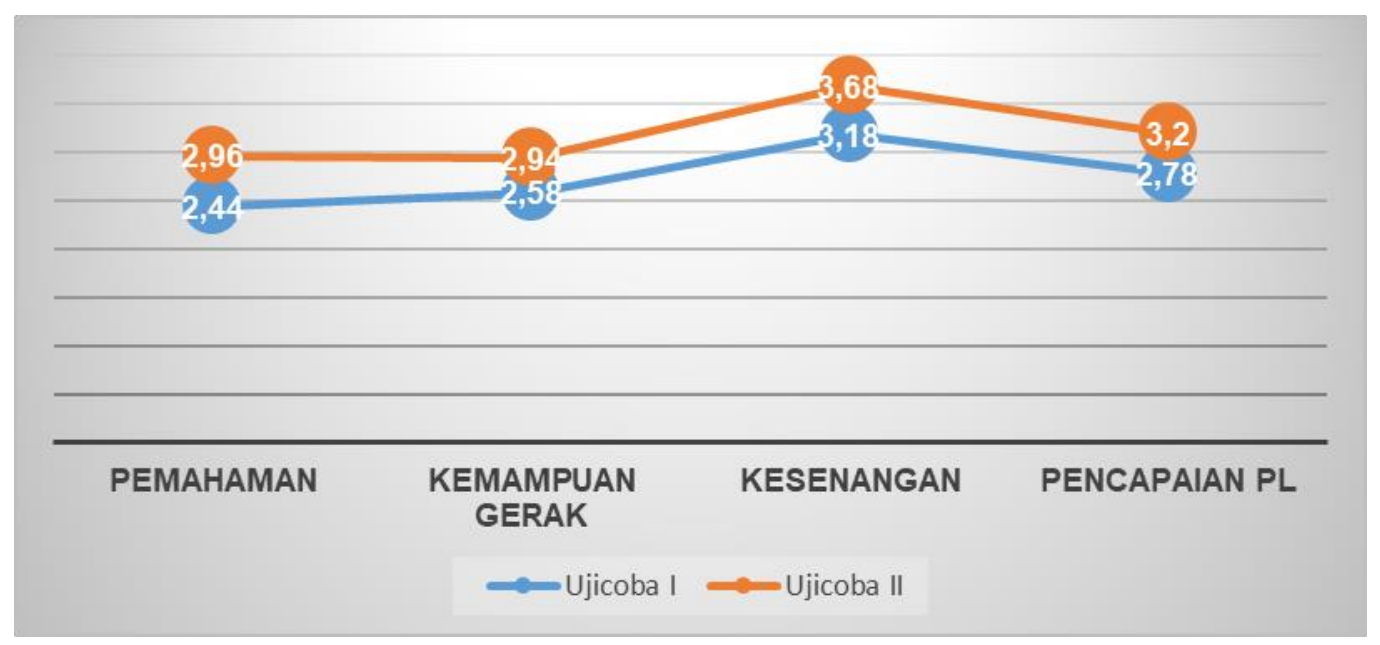

Gambar 1. Rekapitulasi Hasil Penilaian Saat Uji Coba 


\section{PEMBAHASAN}

\section{Pemahaman Siswa}

Berdasarkan hasil penelitian pada tabel 1 diperoleh hasil bahwa permainan tradisional dapat meningkatkan pemahaman siswa. Hasil ini didukung oleh hasil penelitian Gelisli \& Yazici (2015) bahwa permainan tradisional meningkatkan keterampilan dan kompetensi perkembangan kognitif seperti memperhatikan, mengingat, memprediksi, mengamati, mencocokkan, dan memecahkan masalah. Peningkatan ini terjadi disebabkan adanya penggunaan gambar dan simbol karena menyesuaikan dengan perkembangan kognitif siswa yang tengah berada pada tahap praoperasional. Pada tahap ini siswa mulai mempresentasikan dunianya dengan kata-kata, gambar, membangun konsep, dan mulai memberikan alasan yang tetap (Santrock, 2014). Hal menjadikan siswa mampu untuk mengenali dirinya dengan lebih baik dan merupakan hal penting untuk perkembangan kognitif siswa (Spinath \& Spinath, 2005).

Selain itu juga, perkembangan kognitif siswa berkembang dalam bentuk pengetahuan, kreativitas, dan imaginatif (Payne \& Isaacs, 2017). Kemampuan perkembangan irnaginatif ditandai dengan adanya kemampuan berpikir dengan menggunakan simbol dan diikuti dengan berkembangnya kemampuan pemahaman mengenai ruang, korelasi sebab akibat, pengenalan diri, pengelompokkan, dan pengenalan angka (Pagani et al., 2013). Adanya penggunaan simbol dalam berpikir sangat rnembantu siswa dalam mengingat dan memikirkan hal-hal yang tidak hadir secara fisik.

\section{Keterampilan Gerak}

Hasil penelitian yang terdapat pada tabel 2 menunjukkan bahwa permainan tradisional yang dimodifikasi dapat meningkatkan keterampilan gerak siswa meskipun peningkatan terjadi tidak signifikan. Peningkatan yang terjadi disebabkan permainan tradisional merupakan komponen pembelajaran yang dapat mengembangkan keterampilan gerak fundamental (Akbari, Abdoli, Shafizadeh, Khalaji, Hajihosseini, \& Ziaee, 
2009; Suherman, Dapan, Guntur, \& Muktiani, 2019). Atas dasar tersebut, Aktivitas gerak yang terdapat dalam permainan tradisional yang dimodifikasi berupa aktivitas gerak fundamental. Dasar pemilihan gerak fundamental sebagai keterampilan gerak dalam mencapai PL karena gerak fundamental merupakan elemen dan memiliki peran penting dalam pencapaian PL siswa (Edwards, Bryant, Keegan, Morgan, \& Jones, 2017).

Gerak fundamental merupakan suatu tahapan yang menjadikan siswa secara aktif untuk mengeksplorasi kemampuan gerak dalam tubuhnya dan berkembang sebagai hasil belajar siswa mengenai cara untuk merespon suatu rangsangan dalam bentuk pengendalian gerak dan keterampilan gerak. Gerak fundamental sangat dipengaruhi oleh kematangan, tuntutan tugas, faktor lingkungan (Goodway, Ozmun, \& Gallahue, 2019). Pemilihan gerak fundamental sebagai aktivitas gerak karena pada usia SD kelas satu disebabkan perkembangan gerak siswa berada pada tahap perkembangan gerak fundamental.

Selain itu juga, peningkatan keterampilan gerak siswa disebabkan karena permainan tradisional yang digunakan telah dimodifikasi sesuai dengan prinsip pengembangan permainan yaitu disusun secara sederhana agar siswa mudah untuk melakukan dan mempelajari permainan tersebut, harus mampu meningkatkan dan mengembangkan kemampuan gerak siswa, mampu membuat keputusan selama permainan berlangsung, harus bisa rnencapai dan mengembangkan tujuan dari permainan, dan mengkaitkan dengan prinsip pembelajaran (Butler \& Griffin, 2010).

Aspek-aspek yang penting yang diperhatikan dalam memodifikasi permainan tradisional yaitu jenis aktivitas gerak yang modifikasi disesuaikan dengan perkembangan siswa, menggunakan model gerak yang beragam, meningkatkan keterampilan dan kebugaran, mendorong siswa untuk melakukan aktivitas fisik, memfasilitasi aktivitas pembelajaran, memaksimalkan waktu pembelajaran aktif, mengajarkan kompetisi dan kerjasama secara tidak langsung, memiliki keterkaitan dengan materi pembelajaran, dan proses penilaian dilakukan secara 
kontinyu (Kovar, 2012). Adanya penerapan prinsip dan memperhatikan aspek-aspek pengembangan pembelajaran gerak untuk siswa, memudahkan siswa dalam melakukan permainan tradisional tersebut. Selain itu juga permainan tradisional yang dimodifikasi menjadi semakin baik untuk diimplementasikan dan bisa mencapai tujuan yang telah ditetapkan.

Poin penting lainnya yang berkontribusi terhadap peningkatan keterampilan gerak siswa yaitu permainan tradisional yang dimodifikasi membantu siswa untuk mengembangkan keterampilan gerak. Kesesuaian pemilihan gerak fundamental sebagai aktivitas gerak dalam permainan tradisional yang dimodifikasi berkontribusi terhadap peningkatan keterampilan gerak yang dicapai siswa meskipun peningkatannya tidak signifikan. Hal ini dikarenakan ada pembelajaran gerak terdiri atas beberapa tahapan yaitu kognitif, asosiatif, dan otomatisasi (Coker, 2017). Selain itu juga, dalam belajar suatu keterampilan gerak membutuhkan waktu untuk menguasainya (Silverman \& Mercier, 2015). Pada penelitian ini, uji coba yang dilakukan hanya dua kali (4 uji coba) yang memungkinkan siswa berada pada tahap asosiatif yaitu tahapan mengasosiasikan pengetahuan dan keterampilan gerak agar gerak yang dihasilkan menjadi lebih dikuasai.

Banyak manfaat yang diperoleh siswa dalam belajar keterampilan gerak diantaranya mengenal gerak tubuh, kesadaran akan tubuh, kesadaran ruang, kualitas gerak, dan kaitan antara kemampuan gerak dan anggota tubuh (Abels \& Bridges, 2010), meningkatkan pencapaian akademik siswa karena dipengaruhi adanya peningkatan kemampuan kognitif (Fedewa \& Ahn, 2011; Payne \& Isaacs, 2017; Tandon et al., 2016), dan meningkatkan kebugaran, kesehatan psikologi dan mental (Lobstein et al., 2015). Besarnya manfaat yang diperoleh siswa dalam belajar keterampilan gerak seharusnya menjadi perhatian serius bagi orang tua dan guru. Siswa yang belajar keterampilan gerak tidak hanya meningkatkan kemampuan geraknya, melainkan juga dapat meningkatkan kemampuan kognitif, afektif, dan sosialemosional. 


\section{Kesenangan Siswa}

Hasil penelitian yang terdapat pada tabel 3 menunjukkan bahwa permainan tradisional dapat meningkatkan aspek kesenangan siswa karena dilakukan sambil bermain dan merupakan aspek yang mengalami peningkatan secara signifikan. Peningkatan yang terjadi disebabkan permainan tradisional merupakan permainan yang menyenangkan bagi siswa dan selaras dengan aturan pembelajaran gerak harus dilaksanakan secara konsisten dan dilaksanakan dengan cara yang menyenangkan bagi siswa (Domville et al., 2019). Peningkatan terjadi juga disebabkan bermain merupakan aktivitas utama yang dilakukan oleh siswa (Goodway et al., 2019). Selain itu juga, adanya penggunaan pendekatan bermain menjadikan siswa sangat menyenangi semua permainan tradisional yang digunakan.

Bermain yang dilakukan dengan melakukan aktivitas gerak akan berdampak pada perkembangan motorik, afektif, dan sosial (Kovar, 2012), meningkatkan perkembangan kesehatan (Byl \& Kloet, 2014), menimbulkan perubahan positif dalam indeks fisiologis dan antropometrik kesehatan siswa yang memiliki berat badan normal dan obesitas (Lambrick, Westrupp, Kaufmann, Stoner, \& Faulkne, 2016). Hal ini yang menjadikan bermain merupakan aktivitas yang penting untuk dilakukan oleh siswa.

\section{Capaian PL}

Berdasarkan hasil analisis terhadap ketiga aspek yang terdapat pada tabel 4, permainan tradisional yang dimodifikasi mampu meningkatkan pencapaian PL siswa. Hasil yang dicapai disebabkan permainan tradisional memberikan kesempatan kepada siswa untuk melakukan aktivitas gerak sehingga meningkatkan kesempatan dalam pencapaian PL siswa (Castelli, Centeio, Beighle, Carson, \& Nicksic, 2014). Siswa akan meningkat kemampuan berpikirnya, kemampuan dalam melakukan geraknya, dan senang dalam melakukan aktivitas gerak. Hal ini selaras dengan pernyataan Sun (2015) bahwa PL merupakan pendekatan holistik tubuh dan pikiran yang terintegrasi untuk 
dalam melakukan aktivitas fisik dalam mencapai pengetahuan kognitif yang diharapkan, kompeten secara fisik, dan termotivasi secara mental untuk kehidupan yang aktif secara fisik sepanjang umur. Selain itu juga, permainan tradisional memberikan kesempatan kepada siswa untuk melakukan aktivitas gerak semakin meningkatkan kesempatan dalam pencapaian PL siswa (Castelli et al., 2014).

Penelitian sebelumnya permainan tradisional memiliki manfaat yang dapat membangun karakter siswa (Nur, 2013), meningkatkan keterampilan sosial (Irmansyah, Lumintuarso, Sugiyanto, \& Sukoco, 2020; Perdani, 2013), mengembangkan kemampuan fisik dan motorik siswa (Hanief \& Sugito, 2015), dan mengendalikan emosi (Lavega, Alonso, Etxebeste, Lagardera, \& March, 2014). Dari beberapa hasil tersebut belum menunjukkan bahwa permainan tradisional dapat meningkatkan pemahaman siswa dalam bermain dan mendorong penerapan pola hidup aktif dengan menimbulkan rasa senang siswa dalam bermain. Oleh karenanya, temuan dari hasil penelitian ini merupakan hal baru dalam berkaitan dengan manfaat yang diperoleh siswa SD dalam melakukan permainan tradisional.

Hasil penelitian yang dilakukan mampu membuktikan bahwa permainan tradisional yang dimodifikasi mampu mendorong tingkat pemahaman, keterampilan gerak, dan meningkatkan kesenangan siswa. Adanya hasil ini diharapkan bisa memunculkan motivasi, kepercayaan diri dan kemampuan gerak, dan berinteraksi dengan lainnya sehingga siswa bisa memiliki kesadaran akan kemampuan dirinya dan percaya terhadap kemampuan dirinya, mengekspresikan dan berkomunikasi dengan orang lain, memiliki pengetahuan dan pemahaman terhadap kemampuan dirinya, dan selalu aktif dalam aktivitas sehari-hari (Whitehead, 2013).

$\mathrm{PL}$ juga merupakan konsep yang relevan dalam istilah pendidikan pedagogis dan menghubungkan keterampilan belajar secara fisik, psikologis, dan perilaku. Untuk itu, sudah seharusnya dijadikan poin penting konsep PL untuk diimplementasikan dalam pembelajaran penjas (Giblin et al., 2014). Hal ini disebabkan, PL merupakan dasar penting 
dalam menstimulus perkembangan siswa secara optimal (Roetert \& MacDonald, 2015). Lebih lanjut dijelaskan bahwa peranan PL dalam penjas adalah sebagai suatu konsep atau konstruksi yang mendorong siswa mengorganisasikan pengetahuaan dari pengalaman belajar, menampilkan aktivitas gerak dalam berbagai kesempatan, dan sebagai pribadi secara keseluruhan (Lundvall, 2015).

\section{KESIMPULAN}

Permainan tradisional dapat mengembangkan PL siswa sekolah dasar. Hasil ini berdasarkan adanya peningkatan yang dicapai siswa dalam aspek pemahaman melakukan gerak, keterampilan gerak, dan kesenangan dari uji coba pertama dan kedua. Selain itu juga, adanya peningkatan pencapaian hasil pengukuran PL siswa dari uji coba pertamuan pertama dan kedua.

Hasil yang dicapai disebabkan permainan tradisional yang dimodifikasi sesuai dengan karakteristik perkembangan siswa. Pada aspek pemahaman dalam melakukan gerak disesuai dengan kemampuan berpikir praoperasional siswa. Aspek keterampilan gerak disesuaikan dengan keterampilan gerak fundamental yang merupakan tahapan perkembangan gerak yang terjadi pada siswa. Aspek kesenangan, permainan tradisional yang dikembangkan menggunakan dengan pendekatan bermain dan aktivitas yang dirancang menantang, sehingga menarik minat siswa. Selain itu, modifikasi permainan dilakukan dengan mempertimbangkan prinsip dan aspek pengembangan aktivitas pembelajaran untuk siswa SD.

\section{REFERENSI}

Abels, K. W., \& Bridges, J. M. (2010). Teaching movement education: Foundations for active lifestyles. Champaign II: Human Kinetics.

Akbari, H., Abdoli, B., Shafizadeh, M., Khalaji, H., Haji, H. S., \& Ziaei, V. (2009). The effect of traditional games in fundamental motor skill development in 7-9 year-old boys. 123-129. https://doi.org/10.1080/02701367.2016.1164009.

Butler, J., \& Griffin, L. (2010). More teaching games for understanding: Moving globally. Human Kinetics. 
Byl, J., \& Kloet, B. V. (2014). Physical education for homeschool, classroom, and recreation settings: 102 games with variations. Human Kinetics.

Castelli, D. M., Centeio, E. E., Beighle, A. E., Carson, R. L., \& Nicksic, H. M. (2014). Physical literacy and comprehensive school physical activity programs. Preventive Medicine, 66, 95-100. https://doi.org/10.1016/j.ypmed.2014.06.007.

Coker, C. A. (2017). Motor learning and control for practitioners. New York: Routledge.

Corbin, C. B. (2016). Implications of physical literacy for research and practice: A commentary. Research Quarterly for Exercise and Sport, $87(1)$ 14-27. https://doi.org/10.1080/02701367.2016.1124722.

Domville, M., Watson, P. M., Richardson, D., \& Graves, L. E. F. (2019). Children's perceptions of factors that influence PE enjoyment: a qualitative investigation. Physical Education and Sport Pedagogy, 1-13. https://doi.org/10.1080/17408989.2018.1561836.

Edwards, L. C., Bryant, A. S., Keegan, R. J., Morgan, K., \& Jones, A. M. (2017). Definitions, foundations and associations of physical literacy: a systematic review. Sports Medicine, 47(1), 113-126. https://doi.org/10.1007/s40279-016-0560-7.

Fedewa, A. L., \& Ahn, S. (2011). The effects of physical activity and physical fitness on children's achievement and cognitive outcomes: a meta-analysis. Research Quarterly for Exercise and Sport, 82(3), 521-535. https://doi.org/10.1080/02701367.2011.10599785.

Gelisli, Y., \& Yazici, E. (2015). A study into traditional child games played in Konya region in terms of development fields of children. Procedia-Social and Behavioral Sciences, 197, 1859-1865. https://doi.org/10.1016/j.sbspro.2015.07.247.

Giblin, S., Collins, D., \& Button, C. (2014). Physical literacy: importance, assessment and future directions. Sports Medicine, 44(9), 11771184. https://doi.org/10.1007/s40279-014-0205-7.

Goodway, J. D., Ozmun, J. C., \& Gallahue, D. L. (2019). Understanding motor development: Infants, children, adolescents, adults. Jones \& Bartlett Learning.

Hanief, Y. N., \& Sugito, S. (2015). Membentuk gerak dasar pada siswa sekolah dasar melalui permainan tradisional. Jurnal SPORTIF: Jurnal Penelitian Pembelajaran, 1(1), 100-113. https://doi.org/10.29407/js_unpgri.v1i1.575.

Higgs, C., Balyi, I., Way, R., Cardinal, C., Norris, S., \& Bluechardt, M. (2008). Developing physical literacy: A guide for parents of children ages 0 to 12. Vancouver, BC: Canadian Sports Centres.

Irmansyah, J., Lumintuarso, R., Sugiyanto, F. X., \& Sukoco, P. (2020). 
Children's social skills throught traditional sport games in primaryi schools. Jurnal Cakrawala Pendidikan, 39(1), 39-53. https://doi.org/10.21831/cp.v39i1.28210.

Kovar, S. K. (2012). Elementary classroom teachers as movement educators. McGraw-Hill Companies.

Kurniati, E. (2016). Permainan Tradisional dan Perannya Dalam Mengembangkan Keterampilan Sosial Anak. Jakarta: Kencana.

Lambrick, D., Westrupp, N., Kaufmann, S., Stoner, L., \& Faulkner, J. (2016). The effectiveness of a high-intensity games intervention on improving indices of health in young children. Journal of Sports Sciences, 34(3), 190-198. https://doi.org/10.1080/02640414.2015.1048521.

Lavega, P., Alonso, J. I., Etxebeste, J., Lagardera, F., \& March, J. (2014). Relationship between traditional games and the intensity of emotions experienced by participants. Research Quarterly for Exercise and Sport, 85(4), 457-467. https://doi.org/10.1080/02701367.2014.961048.

Lobstein, T., Jackson-Leach, R., Moodie, M. L., Hall, K. D., Gortmaker, S. L., Swinburn, B. A., ... McPherson, K. (2015). Child and adolescent obesity: part of a bigger picture. The Lancet, 385(9986), 25102520. https://doi.org/10.1016/S0140-6736(14)61746-3.

Lundvall, S. (2015). Physical literacy in the field of physical education-A challenge and a possibility. Journal of Sport and Health Science, 4(2), 113-118. https://doi.org/10.1016/j.jshs.2015.02.001.

Nur, H. (2013). Membangun karakter anak melalui permainan anak tradisional. Jurnal Pendidikan Karakter, https://doi.org/10.21831/jpk.v0i1.1290.

Pagani, L. S., Fitzpatrick, C., \& Barnett, T. A. (2013). Early childhood television viewing and kindergarten entry readiness. Pediatric Research, 74(3), 350-355. https://doi.org/10.1038/pr.2013.105.

Payne, V. G., \& Isaacs, L. D. (2017). Human motor development: A lifespan approach. Routledge.

Perdani, P. A. (2013). Peningkatan keterampilan sosial melalui metode bermain permainan tradisional pada anak TK B. Jurnal Pendidikan Usia Dini, 7(2), 234-250. https://doi.org/10.21009/JPUD.072.10.

Roetert, E. P., \& MacDonald, L. C. (2015). Unpacking the physical literacy concept for K-12 physical education: What should we expect the learner to master? Journal of Sport and Health Science, 4(2), 108112. https://doi.org/10.1016/j.jshs.2015.03.002.

Santrock, J. W. (2014). Essentials of life-span development. McGraw-Hill.

Silverman, S., \& Mercier, K. (2015). Teaching for physical literacy: Implications to instructional design and PETE. Journal of Sport and Health

Science,

$4(2)$,

150-155. 
https://doi.org/10.1016/j.jshs.2015.03.003.

Spinath, B., \& Spinath, F. M. (2005). Development of self-perceived ability in elementary school: The role of parents' perceptions, teacher evaluations, and intelligence. Cognitive Development, 20(2), 190204. https://doi.org/10.1016/j.cogdev.2005.01.001.

Suherman, W. S., Dapan, D., Guntur, G., \& Muktiani, N. R. (2019). Development of a traditional children game based instructional model to optimize kindergarteners'fundamental motor skill. Jurnal Cakrawala Pendidikan, 38(2), 356-365. https://doi.org/10.21831/cp.v38i2.25289.

Sun, H. (2015). Operationalizing physical literacy: the potential of active video games. Journal of Sport and Health Science, 4(2), 145-149. https://doi.org/10.1016/j.jshs.2015.03.006.

Tandon, P. S., Tovar, A., Jayasuriya, A. T., Welker, E., Schober, D. J., Copeland, K., ... Ward, D. S. (2016). The relationship between physical activity and diet and young children's cognitive development: A systematic review. Preventive Medicine Reports, 3, 379-390. https://doi.org/10.1016/j.pmedr.2016.04.003.

Tremblay, M., \& Llyod, M. (2010). Physical literacy measurement the missing piece. Physical \& Health Education Journal, 76(1), 26-30.

Whitehead, M. (2013). Stages in physical literacy journey. ICSSPE Bulletin-Journal of Sport Science and Physical Education, 65. Retrieved from http://www.icsspe.org/sites/default/files/bulletin65_0.pdf\#page=29. Diakses tanggal 13 Januari 2020.

WHO. (2014). Commission on Ending Childhood Obesity hold hearing with non-state actors. Geneva (CH): World Health Organization; 2014.

Wijaya, E. Y., Sudjimat, D. A., \& Nyoto, A. (2016). Transformasi pendidikan abad 21 sebagai tuntutan pengembangan sumber daya manusia di era global. Prosiding Seminar Nasional Pendidikan Matematika, 1(26), 263-278.

Williams, H. G., Pfeiffer, K. A., O'neill, J. R., Dowda, M., Mclver, K. L., Brown, W. H., \& Pate, R. R. (2008). Motor skill performance and physical activity in preschool children. Obesity, 16(6), 1421-1426. https://doi.org/10.1038/oby.2008.214. 